\title{
Is Adaptation a Local Responsibility?
}

\begin{abstract}
Adaptation is now firmly embedded in the societal discourse regarding the management of climate risk. In this discourse, adaptation planning and implementation at the local level is seen as particularly important for developing robust responses to climate change. However, it is not clear whether the mantra that adaptation is local holds true given the multi-level nature of climate risk governance. Using a multi-method approach, this paper examines the extent to which adaptation should be framed as a local issue and, specifically, the role of local government in adaptation relative to other actors. In so doing, the paper first explores the extent to which the local framing of adaptation is embedded in the international adaptation literature. This is followed by a specific case study from Southeast Queensland, Australia, which focuses on the critical examination of the processes of responsibility shifting and taking among actors involved in coastal adaptation planning. Results indicate the assumption that adaptation is local remains widely held in adaptation science, although counter arguments can be readily identified. Interviews with adaptation actors revealed unclear divisions of responsibility for climate change adaptation as a significant constraint on actors' willingness to implement adaptation. Furthermore, attributing responsibility for adaptation to local actors might not necessarily be a robust strategy, due to the existence of particularly strong constraints and value conflicts at local levels of governance. Greater appreciation by researchers and practitioners for the interactions between local actors and those at higher levels of governance in shaping response capacity may contribute to more equitable and effective allocations of responsibilities for adaptation action.
\end{abstract}

Keywords: climate change, adaptation, local scale, multi-level governance, Australia 


\section{Introduction}

Climate change adaptation has now firmly established its place as a crucial and much needed response to global climate change (Adger and Barnett, 2009; Biesbroek et al., 2010; Ford and Berrang-Ford, 2011). Within the international discourse on climate policy, the adaptation needs of developing nations and support for adaptation through various finance mechanisms has evolved to become a key negotiating point and element of policy design (Schipper, 2006). As a consequence, the framing of climate change as a global commons problem that can be addressed by greenhouse gas mitigation has been expanded to account for the differential impacts and adaptive capacities that exist at national and sub-national levels.

At the national level, planning for adaptation has become a major strand of public policy, with many governments creating new institutions to deal with this wicked policy problem (Hallegatte, 2009; Pathwardhan et al., 2009). Although developing nations are recognized as being particularly vulnerable to the effects of climate change, concern for adaptation has grown rapidly in developed nations also due to growing awareness of their vulnerability to climate variability and extreme weather events as well as climate change (Ford and Berrang-Ford, 2011; Preston et al., 2011). However, even in relatively wealthy developed nations, actors have identified a range of constraints that impede adaptation options or their effectiveness including information deficit, economic/financial resources to undertake adaptation, institutional capacity, technological capacity, political challenges, and societal trends (Ford and Berrang-Ford, 2011; Klein et al., 2014; Moser and Ekstrom, 2010; Mustelin, 2011).

In this process of expanding adaptation planning, a strong emphasis has been placed on action at the local level (Corfee-Merlot et al., 2011; Measham et al., 2011), which effectively shifts the discussion of the scale of agency from the global to the local level. For example, adaptation is conceptualised as “a local issue addressing local circumstances and needing local solutions and actions” (BlueScope Steel, 2011, p. 9) and as “always local and regional” (Carter and Raps, 2008, p. 29). Underlying these pecerptions is the principle of subsidiarity, which is the belief that "any particular task should be decentralized to the lowest level of governance with the capacity to conduct 
it satisfactorily” (Marshall, 2008, p. 80), and is essentially a question regarding which level should be responsible for which action. Indeed, those advocating decentralisation continue to claim that "local actors are always able and willing to govern their natural resources effectively (Andersson and Ostrom, 2008, p. 71). At least in the context of developed nations, subsidiarity has manifested as local government being recognized as the key actor for adaptation planning and implementation and therefore the actor with the greatest responsibility (Baker et al., 2012; Edvardsson Bjönberg and Hansson, 2011; Mustelin, 2011; Otto-Banaszak et al., 2010). However, formal governments are not the only actors with local agency. Community-based adaptation, in particular, focuses on "local problems and locally appropriate solutions" and "provides an opportunity to extend the local context of choice” (Ensor and Berger, 2009, p. 231). Hence, formal governments at the local level can work in collaboration with other local actors to pursue adaptation planning and implementation.

While "most adaptations will be undertaken at local level” (Grasso, 2010, p. 26) in terms of practical implementation, the evidence that local scale is best placed to govern adaptation is however more complex. A growing literature on multi-level governance clearly demonstrates that adaptation by local actors is often enabled but more so hindered by broader governance arrangements that include actors at higher levels (Keskitalo, 2010; Lawrence et al., 2013; Simonsson et al., 2011; Urwin and Jordan, 2008). In such multi-level systems of governance, the local level is often the weakest component and thus has limited capacity to plan for long-term adaptation let alone implement adaptation strategies (Measham et al., 2011; Reisinger et al., 2011). Hence, a potential mismatch seems to exist between the concept of the localness of adaptation and its actual implementation at the local scale. Yet, to date, this issue has not been formally problematized or investigated although some critical reflection is starting to emerge (see Amundsen et al., 2010; Baker et al., 2012).

The objective of this paper is to elucidate this issue by addressing two related questions: 1) to what extent is the paradigm of local responses to adaptation embedded in adaptation science, and 2) to what extent is this paradigm consistent with stakeholder perspectives on the governance of adaptation in practice? In addressing these questions, the paper draws on research on cognitive reasoning in the 
framing of adaptation (Preston et al., 2013) to identify the extent to which adaptation is understood as a local process within the adaptation science literature. This is followed by a case study focusing on researchers and practitioners in the region of South East Queensland, Australia (Mustelin, 2013). We define adaptation science broadly as "research that generates knowledge that can inform adaptation and its implementation” (Preston et al., 2013, p. 1). Given the governance context for adaptation in Australia represents important background for the case study, this paper proceeds with an overview of that context.

\section{2) The Australian Adaptation Policy Context}

The Australian governance system is a liberal democracy comprised of three tiers of government: the Federal, state and territory governments, and the local governments. In the distribution of powers, local governments are "a silent partner” (Althaus et al., 2007, p. 88) as they are not recognised in the constitution as having legal mandates, but are arms of state and territory governments (Smith et al., 2011). This division of powers also poses severe challenges to the range of policy instruments available at the local level (Althaus et al., 2997; MacIntosh et al., 2014). State governments have to approve all local government planning schemes, which should align with state planning policies. Local governments are responsible for "land use planning, infrastructure and asset development, operation and maintenance, as well as ensuring community well-being and safety” (Queensland Government, 2009, p. 120) activities that are funded through local property taxes. Local governments, however, remain highly dependent on financial allocations from the state (Althaus et al., 2007). In all encompassing policy issues, Australian governments work together through the Council of Australian Governments (COAG).

All levels of Australian government have engaged in adaptation through different initiatives and programs, although there is no State or Federal mandate to undertake adaptation planning (Gero et al., 2012). The 'economic rationalist paradigm' with its focus on asset loss and disruptions to the business continuity has been, to a great extent, the base of adaptation planning and policy action in Australia (Smith et al., 2011, p. 69). The majority of research and policy discussions have focused especially 
on managing the risks and liabilities posed by sea-level rise to coastal communities (Alexander et al., 2011; Barnett et al., 2013; Standing Committee on Climate Change, Water, Environment and the Arts, 2009; Preston, 2010).

From the perspective of the federal government, the responsibility for coastal adaptation resides with “states, territories, local government, industry and communities” (DCC, 2009, p. 8). Furthermore, according to the Federal government's 2010 position paper, adaptation “is also a shared challenge, and a shared responsibility” (DCCEE, 2010, p. 22). In this context, the Federal role is to share information and invest in science and knowledge to enable other actors to adapt (DCCEE, 2010; Productivity Commission, 2012), which largely reflects a knowledge deficit framing of the adaptation challenge (Adger et al., 2009; Lemos et al., 2012; Tribbia and Moser, 2008).

The costs of adaptation are likewise shared but the brunt would be borne by individuals and businesses. For example, the Department of Climate Change and Energy Efficiency (DCCEE, 2010, p. 22) notes that it is not feasible for government to bear all costs for adaptation or to make decisions "on behalf of individuals and businesses that are better placed to manage their own risks"; a view that clearly favours the principle of subsidiarity and is also strongly reiterated by the Select Council on Climate Change’s (2012) report on adaptation responsibilities. This allocation of responsibility to individuals, communities and businesses assumes that these actors have the capacity and will to undertake adaptation (Andersson and Ostrom, 2008; Burton and Mustelin, 2013; Marshall, 2008). However, this assumption requires critical evaluation in order to reconcile conventional wisdom with adaptation implementation in practice.

\section{3) Methods}

\subsection{Local Adaptation in Adaptation Science}

To explore the frequency with which the notion that adaptation should be pursued at the local level appears in adaptation science, a quantitative content analysis was conducted on peer-reviewed and grey literature containing language commenting on 
the localness of adaptation by using a series of focused key word searches with the Google ScholarTM internet search engine. Google Scholar enables searches for exact phrases within entire documents (as opposed to just titles, abstracts, or keywords) and captures a broader range of literature compared to other conventional databases. In addition, Google Scholar allows 'wild card' searches that enable multiple variants of search terms to be captured with a single search. Using Google Scholar, documents (excluding citations and patents) published over the past 10 years (2003-2012) were identified based on a set of search terms. Search terms were comprised of three components. The first two were identical across each search and consisted of the phrase climate change and the word adaptation. The third search term component varied to reflect different language by which the concept of local adaptation could be expressed (see Appendix Table 1). Documents that were retained included peerreviewed journal articles and masters and doctoral theses as well as grey literature comprised of conference papers, books and book chapters, institutional and project reports, as well as policy briefs. Within each document, the passage of text containing the specific search term was excised from the document and entered into a database. The language was then reviewed to a) validate that it was in fact consistent with the concept of local adaptation and b) if so, to evaluate whether that language endorsed the concept, was critical of the concept, or was neutral. Endorsement meant the assumption was accepted unconditionally. All documents and corresponding text from all search term variants were compiled, and used in the quantitative analysis of the frequency with which the notion of local adaptation appears in the adaptation literature.

\subsection{Perspectives on Local Adaptation from Local Stakeholders}

In addition to the general evaluation of the concept of local adaptation in adaptation science, the current study also sought to explore similar themes in a more specific context. Within Australia, the region of South East Queensland represents a useful case study for exploring adaptation governance as it is considered a 'hotspot' for climate change impacts in Australia (Burton, 2014; Hennessy et al., 2007). As part of this study, 45 individual semi-structured interviews of adaptation researchers and practitioners in the region were conducted between 2010 and 2011. Interview participants included local government officials ( $n=17)$, Queensland state government officials $(n=6)$, adaptation researchers $(n=10)$, non-governmental 
organizations $(n=5)$, and individual residents $(n=7)$. The respondents were identified through snowball sampling, which utilises recommendations from the initial respondents to identify new respondents. The interview process followed an approved human research ethics protocol in terms of contacting respondents, and storing data in anonymous form (Griffith University ENV 3509 HREC). All interviews were audio recorded and transcribed.

The interview protocol was semi-structured with five predefined themes, which aimed to elucidate perceptions regarding climate change risks and adaptation strategies, adaptation as a policy issue, responsibility allocation between actors, public participation in decision- and policy-making, and timescales and evidence for adaptation policy development. These predetermined categories functioned as guidelines but the conversation was always based on upon the individual's knowledge, position and willingness to discuss (Fontana and Frey, 2003). The qualitative data program NVivo 8 (Bazeley, 2007) was used in the analysis. The coding process was based on a combination of existing literature and the predefined and emergent themes from the interviews (Mustelin, 2013) that neither completely relies on existing literature nor only relies on the data itself (Bernard and Ryan, 2010; Dey, 1993).

\section{4) Results}

\section{1. 'Local' Adaptation in Adaptation Science}

The paradigm that adaptation responses should occur predominantly at the local level was prominent in the analysed literature. Of the 129 documents that were identified as containing putative language addressing the localness of adaptation, 59 precent endorsed, 33 percent were neutral and only 8 precent criticised the assumption that adaptation is, in fact, local. For example, documents that endorsed this assumption included statements such as "adaptation is local and short-term” (Bosello et al., 2010, p. 81); “almost all adaptation is local” (Satterthwaite et al., 2010, p. 74); “ultimately, most adaptation is local” (Duffy, 2011, p. 197); “Though climate changes may be global and regional in nature, most adaptation is local and requires community planning and grass roots movements" (Lambert et al., 2011, p. 483); and "We 
recognise that adaptation is local - it happens in specific places albeit sometimes in response to impacts elsewhere” (UK Stationary Office, 2010, p. 34).

The few authors who were critical of the localness of adaptation noted that the assumption faces several challenges including, for example, the complexity of multilevel governance of adaptation. Thornton and Manasfi (2010, p. 134) note that "when socio-ecological systems are linked through vast institutions (eg. global markets) and environmental processes (eg. climate change), the adage that 'all adaptation is local' proves false”. Stressing the role of climate impacts, Burton (2008, p. 1) in turn argues that "the 'adaptation is local' mantra is no longer valid. Climate impacts are pervasive, inevitably crossing geographic and political boundaries”. In a similar fashion, Stern and Kasperson (2010, p. 78) note that "The earlier idea that mitigation is global and adaptation is local has collapsed. It is now widely recognised that adaptation needs national and international cooperation to succeed”. Measham et al. (2011) also question whether 'adaptation is local' mantra is valid given that so often action at the local level is constrained by other levels and networks. Pielke et al. (2007, p. 597-598) also critique the assumption by claiming that "Progress on adaptation is also distorted by the common assumption that marginal adaptation is a local issue, whereas mitigation is a global one”.

Assuming the identified literature is reasonably representative of the discourse regarding the localness of adaptation in research and practice, it reflects a clear bias toward the assumption that adaptation is, or should be, largely a local process. Hence, adaptation practitioners that seek to understand at what level adaptation should be dealt with may therefore focus on local responses. Furthermore, those occupying higher levels in the governance of adaptation that subscribe to the principle of subsidiarity seek to devolve responsibility for adaptation to the local level can find their rationale well supported by the adaptation literature. Nevertheless, it is also clear that dissenting opinions exist in the literature that question whether adaptation is best led from the local level and/or which argue that adaptation governance involves more than local actors alone. Given this disparity in perspectives, more focused exploration of assumptions regarding the localness of adaptation among stakeholders in a common context may yield insights that can lead to a more robust framing of local adaptation responses. 


\subsection{Governance of Adaptation: Stakeholder perspectives}

Interview participants offered a range of perspectives regarding the opportunities and constraints associated with local level responses. Here, insights emerging from the interviews are structured to highlight not only the perspectives of those within local government, but also the relationships between local government and other actors involved in the governance of adaptation. First, such relationships are explored among formal government institutions at the local, state, and federal level. This is followed by an exploration of relationships among a broader array of actors, including communities and residents with local agency. The results portray the different perceptions of who stakeholders perceive as responsible for adaptation.

\subsubsection{Perceptions regarding Multiple Levels of Governance}

Interviews with local and state government representatives revealed several areas of tension regarding who should be acting and taking responsibility for climate adaptation (Table 1). Local government respondents, for example, noted the lack of leadership and guidance in this policy arena from federal and state governments. As noted by one local government interviewee:

"Governments at the local scale really struggle with taking action on the basis of leadership as opposed to taking necessary and urgent action because of imminent financial or economic threat. And when the Commonwealth is not doing anything and the state is not doing much. It makes it very difficult for local government to stick its head out and say we are going to lead in this space” (C1A).

Thus, the respondent concluded that local government cannot take a leading role on a national issue when other levels of goverments are responsible for leading. The need for national guidance was also expressed by a state government respondent who argued it was increasingly difficult to engage with climate change as a policy issue given the lack of consistent approaches at the federal level.

However, other interviewees felt that it was not a question of attributing responsibility to one level or another. Rather, adaptation should be viewed as a shared 
responsibility with engagement across all levels of governments as "it is too big for any one level of government” (C2C). Yet, in this instance, the interviewee still identified national leadership as the key for effective response. Another local government interviewee noted that all levels of government seemed to be engaged in a waiting game to see who would publicly take responsibility for different roles in adaptation and/or be willing to intervene in difficult cases such as facilitating community relocation and/or bearing significant costs associated with adaptation. An interviewee working with all levels of governments noted that often calls for national leadership were merely an indication of unwillingness to make decisions on adaptation at other levels:

\begin{abstract}
"When you hear about the lack of leadership, they are actually saying that they want a higher power to say "you must do this" and take full responsibility for all of the consequences that has been directed to make those decisions. There is a level of fear and denial and unwillingness to make a commitment at this point in time.” (E6)
\end{abstract}

This need for guidance and leadership in relation to adaptation planning was at the time recognised by the state of Queensland ${ }^{1}$. The Queensland Coastal Plan 2011 included the identification of coastal hazard areas and new regulations for future development. This included a mandated application of a minimum sea level-rise scenario of $0.8 \mathrm{~m}$ by 2100 for both State and local government planning. A state government interviewee noted how the new rules and regulations should be seen as an act of responsibility taking by the state: "That is what we have tried to say, just to take decision-making away from the councils and say 'use these figures' and then we have to defend those figures” (QS2). This responsibility taking would promote greater consistency across levels of governments and place the State in a position where it could 'fight' court battles on behalf of local governments if they were challenged by developers and citizens in regard to planning decisions.

However, the issue was not simply choosing figures and estimates for regulations. The state government recognised the complexity involved in first understanding and

\footnotetext{
${ }^{1}$ The research was undertaken during the Queensland Labour government, which had a strong focus on adaptation planning. The new Liberal government, in power since 2012, has not continued with most policy developments specifically focused on climate change.
} 
interpreting climate change science, which largely emerges from the top down, and providing specific guidance to governments at the local level. A state government interviewee reflected over this difficulty in taking responsibility for the provision of adaptation guidance given the dynamics of both the natural environment and governance:

\begin{abstract}
"What is the consistent predictable guidance that the state can give that councils can safely incorporate these issues into their future planning? That's a very hard question because the information changes, the policy environment changes, there's even differences between the states in the scenarios that they're planning for so there is a lot of caution in producing a definitive position on what the climate change scenario will be in 2100 and beyond. So therefore the guidance is not very, very easy for an individual council to use and apply.” (QS6)
\end{abstract}

The same interviewee noted that while there is a need for strategic guidance and regulations from the state to some extent, local governments could not just walk away from responsibility. To the contrary, greater responsibility taking at the state government level may create additional responsibilities for local government. For example, the new regulations for coastal hazards included specific risk assessment methodologies for coastal erosion and inundation that local governments need to use as the basis for future planning. Such assessments require significant expertise, which is rarely found within local governments themselves, and thus local governments had to hire such skills externally at a high price. Hence, while state government took responsibility for establishing policy guidance for managing coastal risks associated with climate change, the costs of assessment, planning and implementation to undertake risk management actions was shifted to the local level without necessarily additional support and resources. One state government interviewee remarked:

\footnotetext{
"The state has come up with a lot of planning instruments, which condition development assessment and need parts of the legislation reflected in planning schemes so they make the rules, but then we take our hands off and leave it to council to implement.... So we made the rules but devolve responsibility” (QS4)
}

Local government interviewees also pointed out that state policies were the main impediment to local adaptation as they restricted local governments' options for the 
selection of adaptation pathways and strategies. Local government interviewees also noted that most issues and costs end up being local government responsibilities including, for example, investments in coastal protection mechanisms. Interviewees also noted that the Queensland Coastal Plan requires local governments to use specific advanced methodologies for coastal erosion assessments and modelling of inundation risks, which translates into additional costs in hiring consultants as such expertise is often not found within local governments. However, such costs were not only shifted between governments but also from government to communities where assets to be protected are located and where revenue for the implementation of management actions is sourced through taxes. Therefore understanding the localness of adaptation requires considering not only formal government institutions, but also how those institutions interact with other actors that affect, and are affected by, adaptation decision-making.

\subsubsection{Perceptions of Community, Individual and Government responsibility}

The discussions around government responsibility versus community and individual responsibility raised a number of issues. Several respondents felt that individuals should not blame the government if they own assets in hazard prone areas, because the financial burden of managing the risk through adaptation measures such as enhanced coastal protection would be shared with other members of the community. This responsibility for loss and damage of properties that are located in potentially hazardous areas raised several conflicting perceptions. Interviewees noted that from a local government perspective, it is the individual's responsibility to protect her own property from coastal hazards. Yet those individuals, once allowed to acquire or build assets, often attributed responsibility for the protection of those assets or compensation for loss and damage to government. While at the surface, this conflict suggests a simple case of mutual aversion to risk taking, for the individual, such situations are complicated by the role of local government in restricting homeowners from undertaking additional protective works and measures:

“It's your problem, yeah. But they won't let you retain. Like your yard is falling into the ocean, but they don't let you do anything, they won't let you come from the beach and put more rock there or retain it. So it's not as bad as what's that policy in Byron Shire? Planned retreat. That is just dumb. You can't give someone 
approval to live there and then say "well if it washes away, it's your problem".

No, I'm sorry, it's not.” (R1A)

Another local government interviewee concluded that the responsibility of local government is to provide information to the community, but it is the responsibility of the individual and the broader community to make decisions as to which risks they are prepared to face: “As long as we let people know what the story is, it's up to them to make their decisions, to be responsible for their own actions” (C2E). Another local government representative noted that people often acquired a sense of security once they were able to purchase a property and assumed that this would guarantee a permanently safe environment.

The shifting of responsibilities for hazard mitigation and adaptation among different actors is ultimately linked to the deliberative processes and power relationships that drive policy agendas. The respondents reflected a perception that politicians were reluctant to take responsibility for leading adaptation efforts when there was a lack of community support for particular policies or measures. Hence, community pressure arising from public perceptions of how adaptation responses, or lack thereof, impact people's lives was identified as a very strong driver of local government's determination of which policies and measures are feasible to implement. While this suggests the potential for local non-governmental actors to assume significant responsibility in adaptation planning and implementation, interviewees also recognised that particular decisions at one level of government could be overridden at other levels in the event of differing agendas, mandates and political aims. Hence, the power of public opinion has differential influence over different elements of the governance network.

Several interviewees also noted that these dynamics and power relationships that determine the allocation of responsibility could change. Currently local governments maintain a policy that "the protection of your property is your business and that it is not our business to protect your property” (C1G). However, this interviewee noted that the courts would over time help in determining which new issues would fall under government responsibility. For example, the responsibility for maintaining beaches under a climate change scenario was a new area of potential government 
responsibility, yet one which remained largely abstract given the on-going deliberation, court cases, and policy uncertainty.

\section{5) Discussion}

The results of the literature review indicate a bias within adaptation science toward the framing of adaptation as a local process. However, the existence of studies that adopt a more nuanced, multi-level perspective on adaptation suggest this framing is incomplete (Keskitalo, 2010; Urwin and Jordan, 2008). Interviews with stakeholders in South East Queensland further illustrate the complexity of adaptation governance and provide insights into stakeholder perceptions on how responsibility for adaptation should be allocated. For example, many local governments and residents rarely have the capacity in terms of skills and resources to plan and implement climate change adaptation strategies or are constrained by other levels and actors in their efforts to do so (Amundsen et al., 2010; Lawrence et al., 2013; Reisinger et al., 2011; Simonsson et al., 2011). And yet, such assumptions often feature prominently in the current adaptation discourse (Mustelin, 2013; Preston et al., 2013).

The case study of South East Queensland suggests a lack of willingness to take leadership and/or responsibility as most actors were busy delegating the responsibility to other actors. Only in the case of the Queensland Coastal Plan 2011 was there a notion of positive responsibility taking where the aim by the state was to promote coherence and offer legal protection for local governments. However, given the rather strained relationships between most State and local governments in Australia in recent years (Measham et al., 2011), this act was not perceived positively by local governments who would have had to bear additional requirements and costs as a result. Following a change of state government in 2012, the Queensland Coastal Plan was however revoked, and recently both Queensland and New South Wales have shifted the responsibility of choosing sea level rise benchmarks from state to local governments. While in one way this provides local governments with more power for decision-making, it simultaneously illustrates the difficulty when power is delegated but without adequate resourcing or lifting of other regulatory constraints. Given that successful adaptation is directly dependent on available resources and capacity to act (Fankhauser et al., 1999), delegation of responsibility but without resources or 
mandates hampers local level action and results in potentially negative responsibility shifting (Conway and Mustelin, 2014).

This observation of a lack of willingness stands in contrast to observations in developing nation contexts regarding leadership and responsibility for adaptation. In developing country contexts, actors are more likely to compete for leadership in and responsibility for high profile policy issues, such as climate adaptation and the environment (Artur and Lillhorst, 2012; Conway and Schipper, 2011). Having a policy mandate on climate adaptation means that financial resources are more likely to be targeted to the particular ministry or department who is seen leading these efforts. Hence, taking responsibility and claiming leadership opens up access to financial resources to support policy development and implementation. Yet, in the Australian context, adaptation leadership is seen to impose extra costs without additional resources and hence represents financial and political risks. Whether this is representative of a significant distinction between developing and developed nations in the governance of adaptation in regards to potential incentives to spur action and responsibility taking need further examination and thought.

While different levels of government acknowledged adaptation as a shared responsibility, local governments, in particular, expected national and state leadership in terms of clear regulations and decisions on which estimates and projections should be followed in the planning process regarding, for example, sea level rise. Waiting for the Federal Government to lead in this policy space to some extent reflects a partial ‘Leadership-in-waiting Myth’ (Moser and Dilling, 2007), which relies on the assumption that someone will step up to lead if actors wait long enough and provides a convenient way to shift responsibility upwards from local level. This stands in contrast to the principle of subsidiarity as the local level is not seen, at least not by the local actors, to be the most effective level in implementing adaptation. In a recent study by Barnett et al. (2013, p. 61) on responsibility for adaptation to sea level rise in Australia, the authors also note that local communities perceived the Federal level as responsible as "they have the capacity to raise the revenue necessary to cover the considerable costs” and few attributed major responsibility to the local level. 
The persistent vacillation among actors regarding responsibility for adaptation in the Australian context could also explain observations in the literature that actors are preparing to adapt (Berrang-Ford et al., 2011; Ford et al., 2011), but not necessarily adapting and/or pursuing capacity building activities that are considered to have relatively low political risk and low cost (Preston et al., 2011). If leadership is one of the key enablers of adaptation, then one would expect documents such as the Select Council on Climate Change’s (2012) responsibility allocation on adaptation among the different levels of Australian governments to bring such leadership forward. As Barnett et al. (2013, p. 1) note, one of the most important barriers to adapting to sealevel rise is "a governance barrier of uncertainty about roles and responsibilities across levels of government and sectors”.

It would therefore seem that multi-level governance arrangements, with clear roles and responsibilities, would increase the effectiveness of adaptation and its implementation (Amundsen et al., 2010), rather than simply delegating responsibility for adaptation to the local government and other local actors. Yet, successful examples of effective multi-level governance remain elusive. Multiple authors have noted that multi-level governance can act as constraint itself (Keskitalo, 2010; Measham et al., 2011; Mustelin, 2013; Moser and Ekstrom, 2010; Reisinger et al., 2011; Simonsson et al., 2011; Urwin and Jordan, 2008) due to the increased complexity and a number of actors that, in the end, can potentially undermine the capacity of the system to operate effectively (Keskitalo, 2010).

\section{Conclusions}

This paper examined the extent to which the mantra that adaptation is local holds true given the multi-level nature of climate risk governance and its complexities. While the discourse within adaptation literature continues to often perceive adaptation as a local level issue, as demonstrated by the case of South East Queensland, in practice the ability of local actors to advance an adaptation agenda effectively is lacking in many ways. This is supported by a growing research focus and literature on constraints and limits to adaptation that address, in particular, adaptation planning and implementation in multi-level governance settings. 
The assumption that adaptation is a local level issue and most effectively implemented at the local scale should therefore warrant further reflection both among scientists and policymakers alike. As Baker et al. (2012, p. 134) remark, future research examining those factors that constrain adaptation "should be sceptical of the habitual preference for local scale solutions, which may be the product of devolution ideology rather than demonstrated effectiveness”. Hence, future adaptation research, planning, and implementation should incorporate investigation and deliberation regarding the particular aspects of the 'localness' of adaptation, and the kinds of factors and issues that in turn necessitate the involvement of higher levels of governance. For this exploration to be useful, its focus should be on critically assessing those examples of adaptation projects, programs, and policies, which seem to have overcome multi-level governance constraints in an effective manner.

\section{References}

Adger, W. N., Barnett, J., 2009. Four reasons for concern about adaptation to climate change. Environ. Plan. A 41(12), 2800-2805.

Adger, W.N., Dessai, S.,, Goulden, M., Hulme, M., Lorenzoni, I., Nelson, D.R., Naess, L.O., Wolf, J., Wreford, A., 2009. Are there social limits to adaptation to climate change? Clim. Change 93(3-4), 335-354.

Alexander, K. S., Ryan, A., Measham, T. G., 2011. Managed retreat of coastal communities: understanding responses to projected sea level rise. J. Environ. Plan. Man. 55(4), 409-433.

Althaus, C., Bridgman, P., Davis, G., 2007. The Australian policy handbook. Crows Nest, N.S.W.: Allen \& Unwin, 2007.

Amundsen, H., Berglund, F., Westskog, H., 2010. Overcoming barriers to climate change adaptation-a question of multilevel governance?. Environ. Plan. C 28(2), 276-289.

Andersson, K., Ostrom, E., 2008. Analyzing decentralized resource regimes from a polycentric perspective. Pol. Sci. 41(1), 71-93.

Artur, L., Hilhorst, D., 2012. Everyday realities of climate change adaptation in Mozambique. Global Environ. Change 22(2), 529-536. 
Baker, I., Peterson, A., Brown, G., McAlpine, C., 2012. Local government response to the impacts of climate change: An evaluation of local climate adaptation plans. Landsc. and Urban Plan.107(2), 127-136.

Barnett, J., Waters, E., Pendergast, S., Puleston, A., 2013. Barriers to adaptation to sea level rise: The legal, institutional and cultural barriers to adaptation to sea level rise in Australia. National Climate Change Adaptation Research Facility, Gold Coast, $85 \mathrm{p}$.

Bazeley, P., 2007. Qualitative data analysis with NVivo. Los Angeles; London: SAGE.

Bernard, H. R., Ryan, G. W., 2010. Analyzing qualitative data: systematic approaches. Thousand Oaks, Calif.: Corwin.

Berrang-Ford, L., Ford, J. D., Paterson, J., 2011. Are we adapting to climate change? Global Environ. Change 21(1), 25-33.

Biesbroek, G. R., Swart, R. J., Carter, T. R., Cowan, C., Henrichs, T., Mela, H., et al., 2010. Europe adapts to climate change: Comparing National Adaptation Strategies. Global Environ. Change 20, 440-450.

BlueScope-Steel, 2011. Submission to Productivity Commission inquiry into barriers to effective climate change adaptation. BlueScope-Steel.

Bosello, F., Carraro, C., De Cian, E., 2010. Climate policy and the optimal balance between mitigation, adaptation and unavoided damage. Clim. Change Econom. 1(02), $71-9$.

Burton, I., 2008. Beyond borders: the need for strategic global adaptation. Sustainable Development Opinion Policy Brief. December. London: International Institute for Environment and Development (IIED).

Burton, P., Mustelin, J., 2013. Planning for Climate Change: Is Greater Public Participation the Key to Success? Urban Pol. Res. 1-17.

Burton, P., (Ed) 2014. Responding to climate change: lessons from an Australian hotspot. Collingwood, Victoria, Australia, CSIRO Publishing.

Carter, L., Raps, B., 2008. Adapting to climate change: it is just better planning. Basins and Coasts 2(1), 29-31.

Conway, D., Mustelin, J., 2014. Strategies for improving adaptation practice in developing countries. Nature Clim. Change, 4(5), 339-342.

Corfee-Morlot, J., Cochran, I., Hallegatte, S., Teasdale, P.-J., 2011. Multilevel risk governance and urban adaptation policy. Clim. Change, 104 (1), 169-197.

DCC, 2009. Climate Change Risks to Australia's Coasts. Department of Climate Change, Commonwealth of Australia. 
DCCEE, 2010. Adapting to Climate Change in Australia: An Australian Government Position Paper. Department of Climate Change and Energy Efficiency, Commonwealth of Australia, Canberra.

Dey, I., 1993. Qualitative data analysis: a user-friendly guide for social scientists. London: Ebooks Corporation, New York: Routledge.

Duffy, D. C., 2011. No room in the ark?: Climate change and biodiversity in the pacific islands of Oceania. Pacific Conserv. Bio. 17(3), 192-200.

Edvardsson Björnberg K., Hansson SO., 2011. Five Areas of Value Judgement in Local Adaptation to Climate Change. Local Gov. Stud. 37(6), 671-687.

Ensor, J., Berger, R., 2009. Community-based adaptation and culture in theory and practice. In: Adger, N., Lorenzoni, I., O’Brien, K.L. (Eds.), Adapting to Climate Change: Thresholds, Values, Governance Cambridge, Cambridge University Press, pp. 227-254.

Fankhauser, S., Smith, J. B., Tol, R. S. J., 1999. Weathering climate change: some simple rules to guide adaptation decisions. Ecol. Econom. 30(1), 67-78.

Fontana, A., Frey, J. H., 2003. The Interview: From Structured Questions to Negotiated Text. In: N. K. Denzin, N.K., Lincoln, Y.S. (Eds.), Collecting and Interpreting Qualitative Materials. Thousand Oaks, London and New Delhi SAGE Publications, pp. 61-106.

Ford, J. D., Berrang-Ford, L., 2011. Introduction. In: Ford, J.D., Berrang-Ford, L. (Eds.), Climate Change Adaptation in Developed Nations. Springer Netherlands, pp. 3-20.

Ford, J. D., Berrang-Ford, L., Paterson, J., 2011. A systematic review of observed climate change adaptation in developed nations. Clim. Change 106(2), 327-336.

Gero, A., Kuruppu, N., Mukheibir, P., 2012. Cross-Scale Barriers to Climate Change Adaptation in Local Government, Australia - Background Report. Prepared for NCCARF by Institute for Sustainable Futures, University of Technology, Sydney.

Grasso, M., 2010. Justice in funding adaptation under the international climate change regime Dordrecht; New York: Springer, c2010.

Hallegatte, S., 2009. Strategies to adapt to an uncertain climate change. Global Environ. Change 19(2), 240-247.

Hennessy, K., Fitzharris, B., Bates, B. C., Harvey, N., Howden, S. M., Hughes, L., Salinger, J. \& Warrick, R., 2007. Australia and New Zealand. In: Parry, M. L., Canziani, O. F., Palutikof, J. P., Van Der Linden, P. J. \& Hanson, C. E. (eds.) Climate Change 2007: Impacts, Adaptation and Vulnerability. Contribution of Working Group II to the Fourth Assessment Report of the Intergovernmental Panel on Climate Change. Cambridge: Cambridge University Press. 
Keskitalo, C. E. H., 2010. Introduction- Adaptation to climate change in Europe: Theoretical Framework and Study Design. In: Keskitalo, C.E.H. (Ed.), Developing Adaptation Policy and Practice in Europe: Multi-level Governance of Climate Change (1st ed.). Dordrecht Heidelberg London New York: Springer Science+Business Media, pp. 1-38.

Klein, R.J.T., Midgley, G.F., Preston, B.L., Alam, M., Berkhout, F.G.H., Dow, K. \& Shaw, M.R., 2014. Adaptation opportunities, constraints and limits. In: Climate Change 2014: Impacts, Adaptation, and Vulnerability. Part A: Global and Sectoral Aspects. Contribution of the Working Group II to the Fifth Assessment Report of the Intergovernmental Panel on Climate Change. Field, C.B., Barros, V.R., Dokken, D.J., Mach, K.J., Mastrandrea, M.D., Bilir, T.E., Chatterjee, M., Ebi, K.L., Estrada, Y.O., Genova, R.C., Girma, B., Kissel, E.S., Levy, A.N., MacCracken, S., Mastrandrea, P.R., White, L.L. (Eds). Cambridge University Press, Camridge, United Kingdom and New York, NY, USA, pp. 899-943.

Lambert, J. H., Troccoli, A., White, K. D., Karl, H., Yumagulova, L., Sterin, A., 2011. Adaptation of inland systems to climate change with challenges and opportunities for physical, social, and engineering disciplines. In: Climate, NATO Science for Peace and Security Series C: Environ. Security, Springer, Netherlands, pp. 479-490.

Lawrence, J., Sullivan, F., Lash, A., Ide, G., Cameron, C., McGlinchey, L., 2013. Adapting to changing climate risk by local government in New Zealand: institutional practice barriers and enablers. Loc. Environ. 1-23.

Lemos, M.C., Kirchhoff, C.J., Ramprasad, V., 2012. Narrowing the climate information usability gap. Nature Clim. Change 2, 789-794.

MacIntosh, A., Foerster, A., McDonald, J., 2014. Policy design, spatial planning and climate change adaptation: a case study from Australia. Journal of Environ. Plann. and Man. 1-22.

Marshall, G., 2008. Nesting, Subsidiarity, and Community-based environmental Governance beyond the Local Scale. Inter. Journal of the Commons 2 (1), 75-97.

Measham, T., Preston, B., Smith, T., Brooke, C., Gorddard, R., Withycombe, G., et al., 2011. Adapting to climate change through local municipal planning: barriers and challenges. Mitig. Adapt. Strat. Global Change 16(8), 889-909.

Moser, S. C., Dilling, L., 2007. Toward the social tipping point: creating a climate for change. In: Moser , S.C., Dilling, L. (Eds.), Creating a climate for change: communicating climate change and facilitating social change. Cambridge, U.K.; New York: Cambridge University Press, pp. 491-516.

Moser, S., Ekstrom, J., 2010. A framework to diagnose barriers to climate change adaptation. PNAS 107 (51), 22026-22031. 
Mustelin, J., 2011. Tackling Unknown Uncertainty through Adaptation: The Case of South East Queensland. Paper presented at the 3rd World Planning Schools Congress, Track 20 (Climate Change, Risk, Adaptation and Planning).

Mustelin, J., 2013. Ideal ideals or pragmatic reality? An exploration of adaptation 'theory' in policy and practice. PhD Dissertation, Urban Research Program and Griffith Centre for Coastal Management, School of Environment, Griffith University, Australia.

Otto-Banaszak, I., Matczak, P., Wesseler, J. H. H., Wechsung, F., 2010. Different perceptions of adaptation to climate change: a mental model approach applied to the evidence from expert interviews. Reg. Environ. Change 2 (11), 217-228.

Patwardhan, A., Downing, T., Leary, N., Wilbanks, T., 2009. Towards an integrated agenda for adaptation research: theory, practice and policy: Strategy paper. Cur. Opin. in Environ. Sust. 1(2), 219-225.

Pielke, R., Prins, G., Rayner, S., Sarewitz, D., 2007. Climate change 2007: lifting the taboo on adaptation. Nature 445 (7128), 597-598.

Preston, B.L., Westaway, R., Yuen, E., 2011. Climate adaptation planning in practice: an evaluation of adaptation plans from three developed nations. Mitig. Adapt. Strat. Global Change 16(4), 407-438.

Preston, B.L, Mustelin, J., Maloney, M., 2013. Climate adaptation heuristics and the science/policy divide. Mitig. Adapt. Strat. Global Change, 1-31.

Preston, B. J., 2010. The role of courts in adaptation to climate change. In: T. Bonyhandy, Macintosh, A, Macdonald, J. (Eds.), Adaptation to Climate Change: Law and Policy. The Federation Press: Sydney, pp. 157-201.

Queensland Government, 2009. ClimateQ: Towards a greener future. Office of Climate Change, Queensland State Government, Brisbane.

Queensland Government, 2011. Queensland Coastal Plan. Department of Environment and Resource Management, Queensland Government, Brisbane.

Reisinger, A., Wratt, D., Allan, S., Larsen, H., 2011. The Role of Local Government in Adapting to Climate Change: Lessons from New Zealand. In: Ford, J.D., BerrangFord, L. (Eds.), Climate Change Adaptation in Developed Nations: Springer Netherlands, pp. 303-319.

Satterthwaite, D., Hug, S., Pelling, M., Reid, H., Romero Lankao, P., 2011. Adapting to climate change in urban areas: the possibilities and constraints in low- and middleincome nations. Hum. Settle. Disc. Paper Series.

Schipper, L. E., 2006. Conceptual history of adaptation in climate policy. Review of European Comm. \& Inter. Env. Law, 15 (1), 82-92.

Scott, C., Baehler, K., 2010. Adding value to policy analysis and advice. Sydney, 
University of New South Wales Press Ltd.

Select Council on Climate Change, 2012. Roles and responsibilities for climate change in Australia. Paper released at the second meeting of the Select Council on Climate Change. The Council of Australian Government (COAG) Select Council on Climate Change.

Simonsson, L., Swartling, Å. G., André, K., Wallgren, O., Klein, R. J. T., 2011. Perceptions of Risk and Limits to Climate Change Adaptation: Case Studies of Two Swedish Urban Regions. In: Ford, J.D., Berrang-Ford, L. (Eds.), Climate Change Adaptation in Developed Nations: Springer Netherlands, pp. 321-334.

Smith, T. F., Thomsen, D. C., Keys, N., 2011. The Australian Experience. In: Ford, J.D., Berrang-Ford, L. (Eds.), Climate Change Adaptation in Developed Nations: Springer Netherlands, pp. 69-84.

Standing Committee on Climate Change, Water, Environment and the Arts, 2009. Managing our coastal zone in a changing climate: Time to act is now. Parliament of Australia, Canberra.

Stern, P. C., Kasperson, R. E. (Eds.), 2010. Facilitating climate change responses: A report of two workshops on insights from the social and behavioral sciences. National Academies Press, Washington, DC.

Thornton, T. F., Manasfi, N., 2010. Adaptation Genuine and Spurious: Demystifying Adaptation Processes in Relation to Climate Change. Env. Soc.: Adv. Research 1(1), 132-155.

Tribbia, J., Moser, S.C., 2008. More than information: what coastal managers need to plan for climate change. Environ. Science \& Pol. 11(4), 315-328.

UK Stationery Office, 2010. Adapting Institutions to Climate Change: Twenty-Eighth Report (Vol. 7843). Stationery Office/Tso.

Urwin, K., Jordan, A., 2008. Does public policy support or undermine climate change adaptation? Exploring policy interplay across different scales of governance. Global Environ. Change 18(1), 180-191. 
Table 1. Perceptions on responsibility for adaptation between different levels of government.

\begin{tabular}{|c|c|}
\hline Local and State $\rightarrow$ Federal & $\begin{array}{l}\text { - Federal government to educate the public on climate } \\
\text { change } \\
\text { - Lead the issue and give guidance to other levels of } \\
\text { governments } \\
\text { - Disburse funding for other levels } \\
\text { - Determine which side of climate change debate is right }\end{array}$ \\
\hline Local $\rightarrow$ Federal & $\begin{array}{l}\text { - Local government cannot lead a national issue } \\
\text { - Adaptation a shared responsibility across all governments } \\
\text { (but Federal level should lead) }\end{array}$ \\
\hline
\end{tabular}

- Local governments are responsible for responding to climate change

State $\rightarrow$ Local

- State gives the rules but implementation local responsibility

- State can protect local governments through state-wide frameworks and decisions on sea level rise

Local $\rightarrow$ State

- Role of the state to set sea level rise scenarios and give legal protection for local governments

- State determines assessment approaches and methodologies

- State needs to give clear guidance to local governments

- State needs to provide funding with new regulations

Local $\leftarrow$ State

- Local government should be able to determine their own development pathways through anticipatory planning

The arrows in the table indicate the direction of responsibility shifting: $\rightarrow$ shows to whom particular responsibility is attributed whereas $\leftarrow$ shows who is taking responsibility from whom. 
Appendix. Search criteria used with the Google Scholar search engine to identify documents containing putative language consistent with the assumption that adaptation is local. Each search term was comprised of three components: component A = "climate change"; component B = "adaptation" and component $C$ which was variable. The table below summarises the $C$ component and the number of documents identified that were included in the current study.

Table 1. Search criteria (component C) for the Adaptation is Local heuristic (Search Date: 3/10/2013)

\begin{tabular}{|l|l|r|}
\hline Search \# & Search Terms & Number Included \\
\hline A & "adaptation is local" & 47 \\
\hline B & "adaptation is * local" & 58 \\
\hline C & "adaptation * be local" & 5 \\
\hline D & "adaptation is place based" & 5 \\
\hline E & "adaptation is * place based" & 4 \\
\hline F & "adaptation * be place based" & 0 \\
\hline G & "adaptation is community based" & 1 \\
\hline H & "adaptation is * community based" & 2 \\
\hline I & "adaptation * be community based" & 3 \\
\hline J & "adaptation occurs at the local level" & 0 \\
\hline K & "adaptation * occurs at the local level" & 3 \\
\hline L & "adaptation * occur at the local level" & 1 \\
\hline M & "adaptation * implemented at the local level" & 0 \\
\hline N & "adaptation is * implemented at the local level" & 129 \\
\hline Total & & \\
\hline
\end{tabular}

